Formatif: Jurnal Ilmiah Pendidikan MIPA

Vol. 9, No. 2, Juni 2019, pp. 161-172

p-ISSN: 2088-351X

e-ISSN: 2502-5457

DOI: http://dx.doi.org/10.30998/formatif.v9i2.3251

\title{
Understanding of Nature of Science Pre-Service Students and Elementary School Teachers in the Digital Age
}

\author{
Pemahaman Hakikat Sains Mahasiswa PGSD dan Guru Sekolah Dasar di Era \\ Digital
}

\author{
Ai Hayati Rahayu (*) \\ STKIP Sebelas April Sumedang, Jalan Angkrek Situ No 19 Sumedang
}

Ari Widodo

Pendidikan Biologi, Fakultas Pendidikan Matematika dan Ilmu Pengetahuan Alam, Universitas Pendidikan Indonesia, Jalan Dr. Setiabudhi No 229 Bandung

\begin{abstract}
Received: January 28, 2019
Revised: March 17, 2019

Abstract

Accepted: March 18, 2019

Understanding the Nature of science (NOS) is very important in the process of learning science in the digital era. Understanding the nature of good science is expected to minimize conceptual errors. This study aims to identify pre-service student responses and elementary school teachers related to understanding the nature of science in the digital age. The type of research conducted is quantitative descriptive with survey method. The study sample consisted of students and elementary school teachers in Sumedang. The instrument used was a questionnaire with 28 statements using a Likert scale. The results of the study stated that the response of students and teachers to the understanding of science in the digital era was in the good category with a percentage of $68.7 \%$. Further analysis using one way ANOVA turned out to have a significant difference between students' understanding of level 3 and 5. The understanding of male and female NOS was not significantly different. While teachers who have been certified have a better average understanding than teachers who have not been certified
\end{abstract}

Keywords: Nature of science, digital era,

(*) Corresponding Author: $\quad$ ahayati75@gmail.com, 081395207005

How to Cite: Rahayu, A. H. \& Widodo, A. (2019). Understanding of nature of science pre-service students and elementary school teachers in the digital age. Formatif: Jurnal Ilmiah Pendidikan MIPA, 9 (2): 161172. http://dx.doi.org/10.30998/formatif.v9i2.3251

\section{PENDAHULUAN}

Pemahaman tentang hakikat sains atau Nature of Science (NOS) merupakan sesuatu yang penting dalam proses pembelajaran sains. Pemahaman NOS akan memberikan latar belakang, merinci bagaimana sains dan ilmuwan bekerja. Pemahaman tentang bagaimana pengetahuan ilmiah dibuat, divalidasi, dan dipengaruhi (McComas, 2015). Hal ini menunjukkan pentingnya memasukkan unsur NOS dalam program sains sekolah (McComas \& Nouri, 2016). Bahkan Lederman, Abd-El-Khalick, Bell, \& Schwartz (2002) menyebutkan hampir semua ilmuwan, pendidik sains, dan organisasi pendidikan sains telah sepakat untuk membantu siswa mengembangkan konsepsi pengetahuan tentang hakikat sains. 
Formatif: Jurnal Ilmiah Pendidikan MIPA

Vol. 9, No. 2, Juni 2019, pp. 161-172

p-ISSN: 2088-351X

e-ISSN: $2502-5457$

DOI: http://dx.doi.org/10.30998/formatif.v9i2.3251

Terdapat lima argumen singkat mengapa pemahaman NOS penting untuk dipahami. Argumen tersebut yaitu: 1) Utilitarian, memahami NOS diperlukan untuk memahami ilmu pengetahuan dan mengelola benda-benda teknologi dan proses dalam kehidupan sehari-hari, 2) Democratic, memahami NOS diperlukan untuk informasi pengambilan keputusan pada isu-isu socioscientific, 3) Cultural, memahami NOS perlu untuk menghargai nilai ilmu sebagai bagian dari budaya kontemporer, 4) Moral, memahami NOS membantu mengembangkan pemahaman tentang norma-norma komunitas ilmiah yang mewujudkan komitmen moral tentang nilai umum kepada masyarakat, 5) Science learning, memahami NOS memfasilitasi pembelajaran materi mata pelajaran sains (Lederman et al., 2002)

Pentingnya pemahaman NOS juga dikuatkan oleh pendapat McComas (2015) yang menyatakan bahwa NOS adalah bagian sains yang harus diajarkan oleh guru, tetapi masih sering terbengkalai atau kurang mendapat perhatian. NOS dapat memberikan latar belakang yang penting bagi siswa tentang bagaimana sains dan ilmuwan bekerja, kemudian bagaimana pengetahuan ilmiah tercipta, divalidasi, dan dipengaruhi. Lederman et al, (2002) menegaskan bahwa NOS merupakan bagian dari pemahaman hakikat sains yang utuh. Pemahaman ini meliputi sifat empiris, sifat kreatif dan imajinatif, menanamkan social dan budaya, dan sifat tentatif. Sementara (Jumanto \& Widodo, 2018) menyatakan bahwa NOS adalah hakikat pengetahuan yang merupakan konsep yang kompleks melibatkan filosofi, sosiologi, dan histori suatu pengetahuan. Lebih lanjut Lederman (2002) menguraikan bahwa NOS merupakan epistomologi dari sains, yaitu sains sebagai cara untuk memperoleh pengetahuan, nilai dan keyakinan yang melekat pada ilmu pengetahuan dan pengembangannya.

Perdebatan tentang makna NOS tentunya dimiliki oleh para filsuf ilmu pengetahuan, sejarawan sains, dan pendidik sains (Abd-El-Khalick, Bell, \& Lederman, 1998). (Olson, 2018) menyatakan terdapat ketidaksepakatan tentang isi, struktur, dan fokus tujuan NOS. Namun, di luar pertentangan tentang definisi akhir NOS, yang cukup menarik adalah penjelasan aspek NOS yang penting untuk dimasukkan dalam pembelajaran sains di kelas. Pendidik sains telah merekomendasikan berbagai aspek NOS untuk disertakan dalam pengajaran sains. Sebuah meta-analisis oleh Alshamrani dalam (McComas \& Nouri, 2016) meninjau rekomendasi dari berbagai sumber menemukan 12 aspek NOS yang direkomendasikan. Aspek-aspek tersebut yaitu; 1) Scientifik knowledge is not entirely objective; 2) Scientists use creativity; 3) Scientific knowledge is tentative but durable; 4) Scientific knowledge is socially and culturally embedded; 5) Laws and theories are distinct kinds of knowledge; 6) Scientific knowledge is empirically based; 7) There is no universal stepwise scientific method;8) There is a distinction between observations and inferences; 9) Science cannot answer all questions (and is therefore limited in its scope); 10) Cooperation and collaboration are part of the development of scientific knowledge; 11) There is a distinction between science and technology; 12) Experiments have a role in science (McComas \& Nouri, 2016).

Dari dua belas aspek NOS (Jumanto \& Widodo, 2018), serta (Adi \& Widodo, 2018) merangkum sepuluh aspek yang banyak dikemukan oleh para ahli dimana tujuh di antaranya paling sering digunakan. Ketujuh aspek itu adalah empirical based, tentative, theories and law, sociocultural embeddnes, creativity, scientific method, and subjective. Hasil analisisnya dijadikan kriteria standar untuk kembali mengkaji berbagai pandangan para ahli lain tiga tahun terakhir. Hasil dan kajiannya disajikan dalam tabel 1. 
Formatif: Jurnal Ilmiah Pendidikan MIPA

Vol. 9, No. 2, Juni 2019, pp. 161-172

p-ISSN: 2088-351X

e-ISSN: 2502-5457

DOI: http://dx.doi.org/10.30998/formatif.v9i2.3251

Tabel 1. Hasil Analisis Aspek NOS Menurut Ahli Tiga Tahun Terakhir.

\begin{tabular}{|c|c|c|c|c|c|c|c|c|}
\hline $\begin{array}{l}\mathrm{N} \\
\mathrm{o}\end{array}$ & Aspek NOS & $\begin{array}{l}\text { McCo } \\
\text { mas \& } \\
\text { Nouri, } \\
2016\end{array}$ & $\begin{array}{l}\text { (Irzi } \\
\mathrm{k} \text { \& } \\
\text { Nol, } \\
2014 \\
\text { ) }\end{array}$ & $\begin{array}{l}\text { (Ka } \\
\text { mpo } \\
\text { urak } \\
\text { is, } \\
2016\end{array}$ & $\begin{array}{l}\text { (Fern } \\
\text { andes } \\
, \\
\text { Rodri } \\
\text { gues, } \\
\& \\
\text { Ferre } \\
\text { ira, } \\
2017\end{array}$ & $\begin{array}{l}\text { Olso } \\
\text { n, } \\
2018 \\
\text { ) }\end{array}$ & $\begin{array}{l}\text { Kaya, } \\
\text { Erduran } \\
\text { Birdthist } \\
\text { le, \& } \\
\text { McCor } \\
\text { mack, } \\
\text { 2018) }\end{array}$ & $\begin{array}{l}\text { Jml } \\
\text { aspek }\end{array}$ \\
\hline 1 & Scientists use creativity & $\sqrt{ }$ & & & $\sqrt{ }$ & $\sqrt{ }$ & & 3 \\
\hline 2 & Scientific knowledge is Tentative & $\sqrt{ }$ & & & $\sqrt{ }$ & $\sqrt{ }$ & & 3 \\
\hline 3 & $\begin{array}{l}\text { Science is socially and culturally } \\
\text { Embedded }\end{array}$ & $\sqrt{ }$ & $\sqrt{ }$ & $\sqrt{ }$ & $\sqrt{ }$ & $\sqrt{ }$ & $\sqrt{ }$ & 6 \\
\hline 4 & $\begin{array}{l}\text { There is a distinction between } \\
\text { scientific } \\
\text { laws and theories }\end{array}$ & $\sqrt{ }$ & $\sqrt{ }$ & $\sqrt{ }$ & $\sqrt{ }$ & $\sqrt{ }$ & & 5 \\
\hline 5 & $\begin{array}{l}\text { Scientific knowledge is empiricall } \\
\text { based }\end{array}$ & $\sqrt{ }$ & $\sqrt{ }$ & $\sqrt{ }$ & $\sqrt{ }$ & $\sqrt{ }$ & $\sqrt{ }$ & 6 \\
\hline 6 & Methods \& Methodological Rules & $\sqrt{ }$ & $\sqrt{ }$ & $\sqrt{ }$ & $\sqrt{ }$ & $\sqrt{ }$ & & 5 \\
\hline 7 & Science cannot answer all questior & $\sqrt{ }$ & & $\sqrt{ }$ & & $\sqrt{ }$ & & 3 \\
\hline 8 & $\begin{array}{l}\text { Scientists cooperate \& collaborate } \\
\text { certification \& dissemination }\end{array}$ & $\sqrt{ }$ & $\sqrt{ }$ & $\sqrt{ }$ & $\sqrt{ }$ & $\sqrt{ }$ & & 5 \\
\hline 9 & Scientific ethos & $\sqrt{ }$ & & & $\sqrt{ }$ & $\sqrt{ }$ & $\sqrt{ }$ & 4 \\
\hline
\end{tabular}

Memasuki abad 21 setidaknya terdapat lima domain tentang keterampilan abad 21 yang akan menunjang proses pendidikan dimasanya. Kelima domain tersebut adalah digital age literacy, inventive thingking, high productivity, effective communication, dan information technology. Domain digital age literacy terdiri dari 8 aspek, yaitu: basic, scientific, information, visual, technological, multicultural literacy serta global awareness. Sains sebagai salah satu aspek menjadi fokus pembahasan yang cukup menarik, dimana pembelajaran sains di era ini haruslah menyesuaikan dengan tuntutan masanya (Lemke, 2002).

Abad 21 adalah era digital atau disebut juga revolusi digital yang ditandai dengan terjadinya proliferasi komputer dan otomatisasi pencatatan di semua bidang (Tjandrawinata, 2016). Era digital sebagai fase revolusi teknologi mengubah cara beraktivitas manusia dalam skala, ruang lingkup, kompleksitas, dan transformasi dari pengalaman hidup sebelumnya. Hal ini juga berdampak terhadap proses pembelajaran. Menurut Trillling dan Fadel (2009), dalam era digital pembelajaran berorientasi pada gaya hidup digital, alat berpikir, penelitian pembelajaran dan cara kerja pengetahuan. Cara kerja pengetahuan merupakan kemampuan berkolaborasi dalam tim dengan lokasi yang berbeda dan dengan alat yang berbeda. Penguatan alat berpikir merupakan kemampuan menggunakan teknologi dan alat digital. Sedangkan gaya hidup digital merupakan kemampuan untuk menggunakan dan menyesuaikan diri dan pemahaman dengan era digital.

Hal ini dikuatkan Abelson dalam (Nielsen, 2013) yang memandang penting aspek komunikasi. Dia mengemukakan bahwa tanpa komunikasi tidak akan ada ilmu pengetahuan. Efeknya, aspek komunikasi menjadi aspek penting dalam NOS. Jika kita melihat kepada filsafat sains (Siemens, 2014) tentang proses memahami sains di era digital tidak lagi dengan teori-teori konstruktivisme, tetapi dengan konektivisme. Artinya tren pembelajaran beralih dari tradisional kepada teknologi dan jaringan. Prinsip ini 


\section{Formatif: Jurnal Ilmiah Pendidikan MIPA}

Vol. 9, No. 2, Juni 2019, pp. 161-172

p-ISSN: 2088-351X

e-ISSN: 2502-5457

DOI: http://dx.doi.org/10.30998/formatif.v9i2.3251

selaras dengan era digital dimana pemanfaatan teknologi dan alat digital menjadi sesuatu yang vital.

Aspek koperatif dan kolaborasi sebagai aspek NOS yang sangat relevan di era digital ini dikuatkan oleh pendapat (Kereluik, Mishra, Fahnoe, \& Terry, 2013), yang menyatakan bahwa kompetensi yang harus dimiliki untuk menghadapi tantangan abad 21 meliputi foundational knowledge (to know), humanistic knowledge (to value) dan meta knowledge (to act). Salah satu kategori meta knowledge (to act) memiliki subkategori yang sangat penting untuk mengembangkan keterampilan psikomotor yaitu communication and collaboration skills (keterampilan komunikasi dan kolaborasi). Melalui keterampilan komunikasi dan kolaborasi, nantinya anak akan mampu bekerja sama dengan orang lain dengan berbagai macam karakter dalam upaya menghadapi persaingan global di masa yang akan datang. Komunikasi dan kolaborasi merupakan keterampilan yang diperlukan di kehidupan nyata dalam sains, karena penemuan ilmiah terjadi di antara ilmuwan yang berinteraksi satu sama lain. Keterampilan komunikasi dan kolaborasi ini penting dikembangkan sehingga peserta didik dapat bekerjasama dalam perbedaan kelompok sebagai bekal untuk menghadapi era globalisasi abad 21 (Muiz, Wilujeng, Jumadi, \& Senam, 2016).

Keselarasan pemahaman hakikat sains dengan era digital tentunya menjadi sebuah tantangan yang menarik untuk dikaji. Bagaimana memahami hakikat sains dengan memanfaatkan ketrampilan-ketrampilan digital menjadi tantangan para pendidik di era digital ini. Bagaimana pemanfaatan digital dalam memahami perkembangan sains haruslah menjadi landasan dalam mengembangkan hakikat sains. Sehingga perlu kiranya dilakukan penelitian tentang pemahaman hakikat sains di era digital.

\section{METODE}

Metode penelitian yang digunakan termasuk penelitian deskriptif kuantitatif yaitu penelitian untuk mendeskripsikan persentase respon guru terhadap pemahaman hakikat sains di era digital. Pengambilan data dilakukan dengan memanfaatkan digital yaitu secara online. Populasi penelitian yang dituju mahasiswa (calon guru) dan guru sekolah dasar. Sampel diambil dengan menggunakan teknik acak berdasarkan data yang masuk. Berdasarkan randomisasi, diperoleh sampel yang diwakili 40 guru dan 65 mahasiswa tingkat 3 dan 5. Data diperoleh dengan instrumen Non-Tes, yaitu angket (kuisioner) dengan skala Likert $(5,4,3,2,1)$. Instrumen angket meliputi sembilan aspek hakikat sains. Lebih lengkapnya disajikan dalam tabel 2.

Proses penyusunan instrumen dilakukan dengan cara mengkaji literatur aspek NOS dari jurnal-jurnal terbaru. Dari hasil kajian diambil sembilan aspek sains yang paling banyak muncul. Selanjutnya aspek sains dikolaborasi dengan kompetensi di era digital, dan disusun lagi ke dalam indikator-indikator. Terakhir membuat pernyataan-pernyataan yang sesuai dengan indikator yang telah disusun.

Instrumen yang sudah disusun selanjutnya divalidasi. Uji validitas instrumen (angket) dalam penelitian ini menggunakan pengujian validitas konstruk dengan mengacu kepada pendapat ahli (judgment expert) dan teman sejawat yang sedang melakukan penelitian serupa. 
Formatif: Jurnal Ilmiah Pendidikan MIPA

Vol. 9, No. 2, Juni 2019, pp. 161-172

p-ISSN: 2088-351X

e-ISSN: 2502-5457

DOI: http://dx.doi.org/10.30998/formatif.v9i2.3251

Tabel 2. Kisi-kisi Instrumen Hakikat Sains di Era Digital.

\begin{tabular}{|c|c|c|c|}
\hline No & $\begin{array}{l}\text { Aspek Hakikat } \\
\text { Sains } \\
\end{array}$ & Deskripsi & $\begin{array}{c}\text { Pernyataan } \\
\text { nomor }\end{array}$ \\
\hline 1 & Creativity & $\begin{array}{l}\text { Pengetahuan tercipta dari proses kreatifitas } \\
\text { dengan menggunakan teknologi digital }\end{array}$ & $1,2,3$ \\
\hline 2 & Tentative & $\begin{array}{l}\text { Pengetahuan ilmiah dapat berubah dengan } \\
\text { adanya bukti-bukti baru dari data digital }\end{array}$ & $4,5,6,7$ \\
\hline 3 & $\begin{array}{l}\text { Socio,cultural } \\
\text { embeddednes }\end{array}$ & $\begin{array}{l}\text { Pengetahuan ilmiah dipengaruhi lingkungan } \\
\text { sosial budaya masyarakat digital }\end{array}$ & $8,9,10$ \\
\hline 4 & $\begin{array}{l}\text { Theories and } \\
\text { law }\end{array}$ & $\begin{array}{l}\text { Perbedaan teori dan hukum dalam pengetahuan } \\
\text { ilmiah dapat dibuktikan dengan teknologi digital }\end{array}$ & $11,12,13,14$ \\
\hline 5 & Empiris based & Bukti empiris banyak menggunakan bukti digital & $15,16,17$ \\
\hline 6 & $\begin{array}{l}\text { Scientific } \\
\text { method }\end{array}$ & $\begin{array}{l}\text { Metode ilmiah dilakukan melalui proses } \\
\text { menganalisis, mengevaluasi, menginterpretasi, } \\
\text { informasi dan konten digital }\end{array}$ & $18,19,20$ \\
\hline 7 & $\begin{array}{l}\text { Cannot answer } \\
\text { all questioning }\end{array}$ & $\begin{array}{l}\text { Pengetahuan ilmiah dapat diperoleh melalui } \\
\text { informasi dan konten digital namun tidak dapat } \\
\text { menjawab semua pertanyaan }\end{array}$ & 21,22 \\
\hline 8 & $\begin{array}{l}\text { Communication } \\
\text { and } \\
\text { colaboration }\end{array}$ & $\begin{array}{l}\text { Pengetahuan ilmiah dikembangkan melalui } \\
\text { interaksi, kolaborasi dan sharing teknologi } \\
\text { digital }\end{array}$ & 23.24 .25 \\
\hline 9 & Scientific ethos & $\begin{array}{l}\text { Ilmuwan dalam mengembangkan pengetahuan } \\
\text { ilmiah dengan menggunakan teknologi digital } \\
\text { harus berdasarkan norma-norma dan etos ilmiah. }\end{array}$ & $26,27,28$ \\
\hline
\end{tabular}

Data yang masuk sebelumnya dipilih dan dipastikan mengisi secara lengkap. Data dipilih yang mempunyai kesesuaian daerah asal untuk memudahkan pengambilan kesimpulan yaitu daerah Sumedang. Data responden yang terpilih disajikan pada tabel 3.

Tabel 3. Data responden yang masuk melalui angket online

\begin{tabular}{lll}
\hline No & Responden & Jumlah \\
\hline 1 & Guru Sekolah Dasar & 43 orang \\
3 & Mahasiswa PGSD semester 3 & 36 0rang \\
4 & Mahasiswa PGSD semester 5 & 21 orang \\
& Jumlah & 100 orang \\
\hline
\end{tabular}

Tahap selanjutnya, data yang masuk kemudian dilakukan skoring yaitu memberi skor atas jawaban yang diberikan responden kemudian dipersentasekan dan dikategorisasi sesuai dengan kriteria yaitu sangat baik, baik, cukup, kurang, dan sangat kurang. Data dianalisis tiap aspek NOS serta berdasarkan beberapa karakteristik sampel. Analisis mendalam dilakukan untuk mengetahui apakah terdapat perbedaan yang signifikan pemahaman hakikat sains antara mahasiswa tingkat 3 dan 5 serta guru. Teknik analisis menggunakan SPSS one-way anova. 
Formatif: Jurnal Ilmiah Pendidikan MIPA

Vol. 9, No. 2, Juni 2019, pp. 161-172

p-ISSN: 2088-351X

e-ISSN: 2502-5457

DOI: http://dx.doi.org/10.30998/formatif.v9i2.3251

\section{HASIL DAN PEMBAHASAN}

\section{Hasil}

Penelitian menggunakan instrumen pengumpul data berupa angket tertutup yang disebar secara online. Instrumen yang digunakan merupakan hasil kajian literatur tentang hakikat sains di era digital serta sudah divalidasi oleh ahli. Aspek sains yang digunakan meliputi: creativity, tentative, Sociocultural embeddednes, theory and law, empiris base, scientific method, cannot answer all questioning communication and collaboration, scientific ethos. Berikut hasil tanggapan responden terhadap pemahaman hakikat sains di era digital.

Tabel 4 Persentase Respon Guru dan Mahasiswa terhadap Pemahaman Sains Di Era

\begin{tabular}{|c|c|c|c|c|c|c|}
\hline \multirow{4}{*}{ No } & \multirow{4}{*}{ Aspek Hakikat Sains } & \multicolumn{3}{|c|}{ Digital } & \multirow{4}{*}{$\begin{array}{l}\text { Rata- } \\
\text { Rata }\end{array}$} & \multirow{4}{*}{ Kriteria } \\
\hline & & Perse & tase Resp & nden & & \\
\hline & & \multirow{2}{*}{ Guru SD } & \multicolumn{2}{|c|}{ Mahasiswa } & & \\
\hline & & & $\begin{array}{c}\text { Tingkat } \\
3 \\
\end{array}$ & $\begin{array}{c}\text { Tingkat } \\
5\end{array}$ & & \\
\hline 1 & Creativity & 80,7 & 77,4 & 83,4 & 80,5 & Baik \\
\hline 2 & Tentative & 62,3 & 63,6 & 63,8 & 63,2 & Baik \\
\hline 3 & Socio,cultural embeddednes & 76.3 & 73,5 & 82,8 & 77,5 & Baik \\
\hline 4 & Theories and law & 65,7 & 61,9 & 63,3 & 63,6 & Baik \\
\hline 5 & Empiris based & 65,4 & 64,8 & 63,8 & 64,6 & Baik \\
\hline 6 & Scientific method & 73,9 & 67,8 & 70,1 & 70,6 & Baik \\
\hline 7 & $\begin{array}{l}\text { Cannot answer all } \\
\text { questioning }\end{array}$ & 56,5 & 57,2 & 57,6 & 57,1 & Cukup \\
\hline 8 & $\begin{array}{l}\text { Communication and } \\
\text { colaboration }\end{array}$ & 73 & 73,1 & 74,6 & 75,6 & Baik \\
\hline \multirow[t]{3}{*}{9} & Scientific ethos & 66,9 & 68,6 & 67,1 & 67,5 & Baik \\
\hline & Rata-rata & 68,9 & 67,5 & 69,6 & 68,7 & \\
\hline & Kriteria & Baik & Baik & Baik & baik & \\
\hline
\end{tabular}

Pada tabel 4 dapat kita ketahui bahwa tingkat pemahaman hakikat sains guru, mahasiswa tingkat 3 dan tingkat 5 secara berturut-turut mendapat persentase 68,9, 67,5 dan 69,6 dengan kriteria baik. Sehingga secara umum rata-ratanya berada pada skor 68,7\%. Artinya pemahaman guru dan mahasiswa tingkat 3 dan 5 di kabupaten Sumedang secara umum termasuk kategori baik. Dalam kurikulum mahasiswa PGSD tingkat 5 terdapat mata kuliah pembelajaran IPA dimana salah satunya adalah materi hakikat sains. Hal ini cukup membantu pemahaman mereka seperti dikatakan (McComas \& Nouri, 2016) "those who have thought deeply about NOS in classroom recognize far more NOS"

Pemahaman sains mahasiswa PGSD ditinjau dari aspek creativity, tentative, Sociocultural embeddednes, theory and law, empiris base, scientific method, communication and collaboration, scientific ethos memperoleh kriteria baik, sedangkan aspek science cannot answer all questioning memperoleh persentase paling rendah dengan kriteria cukup. Aspek creativity memperoleh persentase paling tinggi dibanding aspek lainnya. Artinya responden menyetujui bahwa kreativitas sangat diperlukan dalam memahami hakikat sains di era digital. Kesadaran ini seiring dengan makin maraknya pemakaian alat digital di masyarakat serta memperkuat hasil penelitian (Ratnawati, 2013) yang menyatakan 79,23\% mahasiswa memahami hubungan antara kreativitas dengan eksperimen yang dilakukan ilmuwan. 
Formatif: Jurnal Ilmiah Pendidikan MIPA

Vol. 9, No. 2, Juni 2019, pp. 161-172

p-ISSN: 2088-351X

e-ISSN: 2502-5457

DOI: http://dx.doi.org/10.30998/formatif.v9i2.3251

Analisis berikutnya berdasarkan karakteristik sampel yaitu jenis kelamin secara umum, serta pemahaman guru Sekolah Dasar berdasarkan usia dan pengalaman yang ditandai dengan sertifikat pendidikan. Berikut gambar jumlah responden berdasarkan jenis kelamin beserta hasil responnya terhadap pemahaman hakikat sains di era digital.

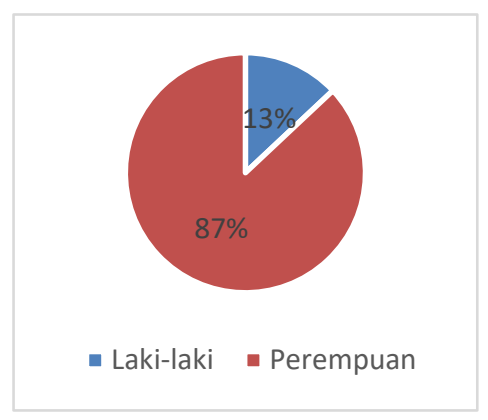

Gambar 1. Persentase jumlah responden berdasarkan jenis kelamin

Berdasarkan gambar 1 dapat kita simpulkan bahwa jumlah responden laki-laki lebih banyak dibandingkan responden perempuan. persentase hasil respon pemahaman hakikat sains di era digital berdasarkan jenis kelamin disajikan pada tabel 5.

Tabel 5 Respon Pemahaman Hakikat Sains Berdasarkan Jenis Kelamin

\begin{tabular}{lll}
\hline No & Gender & Persentase (\%) \\
\hline 1 & Laki-laki & 71 \\
2 & Perempuan & 70 \\
\hline
\end{tabular}

Berdasarkan tabel 5, ditinjau dari perbedaan jenis kelaminnya ternyata responden memiliki rata-rata persentase yang hampir sama, yaitu berturut-turut 71 dan 70 persen. Berdasarkan uji statistic distribusi $t$ tidak terdapat perbedaan yang signifikan di antara keduanya. Hal ini sejalan dengan hasil penelitian (Adi \& Widodo, 2018) mengutip pendapat hasil penelitian Metin, yang menyatakan bahwa berdasarkan uji t test bahwa sikap mahasiswa perempuan lebih positif dibandingkan dengan mahasiswa laki-laki, tetapi untuk guru sekolah dasar tidak ada perbedaan yang signifikan berdasarkan jenis kelamin. Artinya pemahaman responden laki-laki dan perempuan tidak terdapat perbedaan yang signifikan.

Berdasarkan profesinya terdapat responden yang berprofesi sebagai mahasiswa calon guru dan guru Sekolah Dasar. Responden guru dikategorisasi berdasarkan usia dan pengalamannya yang ditandai dengan perolehan sertifikat pendidik. Berikut data lengkapnya.

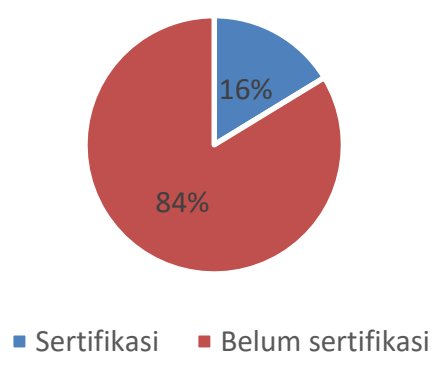

Gambar 2. Jumlah Responden guru berdasarkan sertifikasi pendidik 
Formatif: Jurnal Ilmiah Pendidikan MIPA

Vol. 9, No. 2, Juni 2019, pp. 161-172

p-ISSN: 2088-351X

e-ISSN: 2502-5457

DOI: http://dx.doi.org/10.30998/formatif.v9i2.3251

Gambar 2 menjelaskan bahwa responden guru yang sudah disertifikasi kurang dari jumlah responden yang belum di sertifikasi. Rata-rata guru yang sudah sertifikasi berada pada rentang usia 40-50 tahun. Hasil Respon pemahaman sains guru berdasarkan sertifikasi pendidiknya sebagai berikut.

Tabel 6. Respon Guru terhadap pemahaman hakikat sains berdasarkan sertifikasi Pendidik

\begin{tabular}{ccc}
\hline No & Status sertifikasi & Persentase $(\%)$ \\
\hline 1 & Sudah & 72 \\
2 & Belum & 70 \\
\hline
\end{tabular}

Berdasarkan data dalam tabel 6 kita dapat menyimpulkan bahwa meskipun mempunyai nilai persentase yang sedikit berbeda, tetapi tidak berbeda secara signifikan berdasarkan hasil uji t tes. Hal ini tidak sependapat dengan Fullan yang dikutip oleh (Adi \& Widodo, 2018; Jumanto \& Widodo, 2018) bahwa pengalaman formal dan informal yang terbentuk dalam lingkungan yang kompleks dan dinamis akan memperkuat tingkat pemahaman seseorang. Artinya guru yang sudah disertifikasi walaupun sudah mendapatkan pendidikan dan pelatihan yang dapat memperkaya pengalaman mengajarnya, namun pemahaman hakikat sainnya tidak terlalu jauh berbeda dengan yang belum di sertifikasi.

Data responden guru berdasarkan yang sudah sertifikasi berada pada rentang usia 40-50 tahun. Data ini menarik untuk menganalisis responden guru berdasarkan usianya. Berikut adalah respon guru terhadap pemahaman hakikat sains berdasarkan usianya. Data disajikan dalam tabel 7.

Tabel 7 Respon Guru terhadap pemahaman hakikat sains berdasarkan usia

\begin{tabular}{ccc}
\hline No & Rentang usia & Persentase (\%) \\
\hline 2 & $21-30$ & 70 \\
3 & $31-40$ & 69 \\
4 & $40-50$ & 72 \\
\hline
\end{tabular}

Tabel 7 menyatakan bahwa usia seorang guru tidak selalu menggambarkan tingkat profesionalitasnya. Akan tetapi, pengalaman serta penguatan lewat pelatihanlah yang memperkuat pemahaman. Rata-rata pemahaman guru pada usia 31--40 tahun mengalami penurunan dari guru-guru dengan rentang usia 21--30 tahun, sedangkan usia 40--50 tahun mereka sudah mendapatkan sertifikat pendidik, artinya sudah mendapatkan pelatihan mempunyai rata-rata tanggapan paling tinggi. Walaupun secara uji t tes tidak berbeda secara signifikan.

Untuk menjawab rumusan masalah apakah terdapat perbedaan yang signifikan pemahaman hakikat sains di era digital antara guru Sekolah Dasar dengan mahasiswa tingkat 3 dan 5, maka digunakan analisis SPSS one way anova. Hasilnya disajikan pada tabel 8 . 
Formatif: Jurnal Ilmiah Pendidikan MIPA

Vol. 9, No. 2, Juni 2019, pp. 161-172

p-ISSN: 2088-351X

e-ISSN: 2502-5457

DOI: http://dx.doi.org/10.30998/formatif.v9i2.3251

Tabel 8. Hasil Uji One Way Anova tingkat Pemahaman Hakikat Sains di Era Digital antara Guru SD dan mahasiswa PGSD tingkat 3 dan 5

\begin{tabular}{crrcrc}
\hline & Sum of & \multicolumn{1}{c}{ Mean } \\
& Squares & Df & Square & F & Sig. \\
\hline Between & 376.529 & 2 & 188.264 & 6.3 & .003 \\
$\begin{array}{c}\text { Groups } \\
\text { Within }\end{array}$ & 2875.23 & & & 51 & \\
$\begin{array}{c}\text { Groups } \\
\text { Total }\end{array}$ & 3251.76 & 97 & 29.642 & & \\
& 0 & 99 & & & \\
\hline
\end{tabular}

Berdasarkan tabel 8 terlihat bahwa nilai signifikansi sebesar 0,03 . Karena nilai signifikansi $=0,03$ kurang dari $\alpha=0,05$ maka $\mathrm{H}_{0}$ ditolak, dan $\mathrm{H}_{1}$ diterima. Artinya terdapat perbedaan yang signifikan antara pemahaman hakikat sains guru SD dengan mahasiwa tingkat 3 dan tingkat 5 . Karena $\mathrm{H}_{1}$ diterima maka untuk mengetahui kelompok yang mempunyai perbedaan yang signifikan dilanjutkan dengan uji pos hoc Turkey. Hasil ujinya disajikan pada tabel 9.

Tabel 9. Nilai Sig Hasil Uji Post hoc menggunakan metode Turkey HSD

\begin{tabular}{|c|c|c|c|}
\hline Pemahaman Sains & Guru SD & Mahasiswa Tk 3 & Mahasiswa Tk 5 \\
\hline Guru SD & 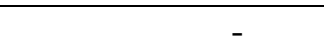 & 0,875 & 0,008 \\
\hline Mahasiswa Tk 3 & 0,875 & - & 0,003 \\
\hline Mahasiswa Tk 5 & 0,008 & 0,003 & - \\
\hline
\end{tabular}

Dari tabel Post Hoc Test di atas memperlihatkan bahwa kelompok yang menunjukan adanya perbedaan rata-rata pemahaman hakikat sains di era digital adalah yang mempunyai nilai Sig kurang dari 0,05. Jadi terdapat perbedaan yang signifikan pemahaman hakikat sains antara mahasiswa tingkat 3 dan tingkat 5. Sedangkan antara guru dan mahasiswa baik tingkat 3 maupun tingkat 5 tidak terdapat perbedaan. Berdasarkan nilai mean different nya mahasiswa tingkat 5 memiliki nilai selisih positif terbesar, sehingga dapat disimpulkan bahwa kelompok mahasiwa tingkat 5 memiliki pemahaman hakikat sains yang lebih baik dari mahasiswa tingkat 3 dan guru.

\section{Pembahasan}

Penelitian ini dilakukan berdasarkan hasil-hasil penelitian terdahulu yang menyimpulkan pentingnya pemahaman hakikat sains dikuasai oleh guru atau siswa dalam proses pembelajaran sains, bahkan dalam kehidupannya sehari-hari. Memasuki era revolusi 4.0 atau dikenal era digital, pembelajaran sains harus mengalami perubahan. Perubahan yang dimaksud bukan hanya menyangkut perubahan konten kurikulum, juga perubahan pedagogi, yaitu perubahan dalam bertindak dari simple action ke arah comprehensive action dan peralihan dominasi pengajaran tradisional menuju pengajaran berbasis teknologi (Afandi, Junanto, \& Afriani, 2016).

Seiring dengan makin banyaknya proses interaksi yang telah berhasil "di digitalisasikan" oleh kemajuan teknologi, maka aspek-aspek hakikat sains harus menyelaraskan dengan perubahan tersebut. Untuk mendapatkan pemahaman hakikat sains yang selaras dengan era digital ini maka dilakukan analisis hakikat sains di era digital dengan berdasarkan literature-literatur terdahulu. 
Vol. 9, No. 2, Juni 2019, pp. 161-172

p-ISSN: 2088-351X

e-ISSN: 2502-5457

DOI: http://dx.doi.org/10.30998/formatif.v9i2.3251

Berdasarkan hasil analisis aspek NOS, yang paling tinggi persentasenya adalah aspek creativity, sedangkan yang terendah adalah science cannot answer all question. Hasil analisis aspek creativity ini menunjukan nilai persentase paling tinggi yaitu $80 \%$ dengan kategori baik. Artinya responden sudah mempunyai pemahaman bahwa pengetahuan ilmiah tercipta dari imajinasi, kreativitas, dan penalaran logis manusia yang terus berkembang dan didasarkan pada perencanaan, pengamatan, dan simpulan dengan menggunakan teknologi digital. Pentingnya aspek kreativitas dalam NOS sesuai dengan pendapat (Nielsen, 2013) yang menyatakan para ilmuwan menggunakan kreativitas dan inovasi-inovasi untuk menemukan hal baru. Hal ini sudah cukup baik dipahami oleh mahasiswa maupun guru Sekolah Dasar. Makin terbukanya informasi dan teknologi telah membuka cakrawala pandangan responden untuk makin kreatif termasuk dalam penemuan ilmiah.

Aspek science cannot answer all questioning, mendapat nilai persentase paling rendah yaitu $57,1 \%$. Artinya responden masih memahami pengetahuan ilmiah dapat diperoleh melalui informasi dan konten digital tetapi mereka mempunyai paradigma bahwa hasilnya dapat menjawab atau memecahkan semua pertanyaan atau masalah. Makin maraknya alat digital saat ini membuat efek negatif ketergantungan orang terhadap alat digital. Sehingga memiliki pemahaman bahwa sains dapat menjawab semua pertanyaan dan permasalahan. Pemahaman ini tentunya harus dikoreksi. Aspek sains idak dapat menjawab semua pertanyaan mendukung aspek sains bersifat tentatif. Artinya pengetahuan akan berubah ketika muncul bukti-bukti baru, yang akhirnya sains tersebut tidak akan dapat menjawab masalah tersebut.

Aspek yang masih mendapat persentase kurang adalah aspek tentative dan theory and law. Persentase kedua aspek di atas sekitar 63\%. Pada aspek ini responden sudah memahami bahwa pengetahuan ilmiah bersifat tentatif, yang berarti bahwa ilmu pengetahuan tidak kekal dan memungkinkan untuk berubah seperti pendapat (Nielsen, 2013). Dalam penelitian ini, Rata-rata $63,2 \%$ responden memiliki pemikiran bahwa pengetahuan ilmiah dapat berubah dengan adanya bukti-bukti digital yang baru. Sementara pengetahuan juga dipengaruhi oleh sosial budaya masyarakat serta harus memerhatikan etika. Banyak permasalahan berkaitan dengan aspek ini tidak langsung dapat dijawab oleh pengetahuan ilmiah.

Aspek teori and law menyatakan bahwa terdapat perbedaan antara teori dan hukum yang dapat dibuktikan dengan bukti digital. Namun aspek ini juga menekankan pada pemahaman tentang definisi teori dan hukum. Teori dan hukum merupakan dua hal yang memiliki kajian tentang alam semesta dari sisi yang berbeda. Artinya, antara hukum dan teori tidak ada keterkaitan sama sekali (Nielsen, 2013). Dalam penelitian ini masih adanya miskonsepsi bahwa terdapat hubungan antara teori dan hukum dimana terdapat hierarki atau tingkatan antara teori dan hukum. Masih banyak responden tidak mengetahui definisi teori dan hukum serta menyebutkan bahwa teori yang telah melalui pengujian berulang akan menjadi suatu hukum melalui pembuktian digital. Hal ini sesuai dengan hasil penelitian (Annisa, 2017), masih terdapat miskonsepsi antara pengertian hukum dan teori.

Instrumen hakikat sains di era digital disebarkan secara daring kepada mahasiswa dan guru sekolah dasar untuk mengetahui seberapa jauh respon mereka terhadap pemahaman hakikat sains di era digital. Responden yang berpartisipasi kebanyakan berada pada rentang usia 50 tahun ke bawah. Hal ini menandakan bahwa responden di atas usia 50 tahun masih belum cukup familiar dengan digital. Perangkat digital cukup banyak digunakan oleh orang pada usia di bawah 50 tahun. Kesimpulan ini diperkuat oleh data bahwa tidak ada responden guru yang berusia di atas 50 tahun ikut berpartisipasi. 


\section{Formatif: Jurnal Ilmiah Pendidikan MIPA}

Vol. 9, No. 2, Juni 2019, pp. 161-172

p-ISSN: 2088-351X

e-ISSN: 2502-5457

DOI: http://dx.doi.org/10.30998/formatif.v9i2.3251

Pemahaman hakikat sains dipengaruhi oleh interaksi individu dengan lingkungannya. Mahasiswa tingkat 5 lebih baik pemahamannya karena mereka sudah mendapatkan materi tentang konsep dasar IPA yang salah satu materinya membahas tentang hakikat sains. Hal ini menguatkan pendapat (McComas \& Nouri, 2016) "those who have thought deeply about NOS in classroom recognize far more NOS". Pemahaman hakikat sains pada guru relatif lebih rendah secara keseluruhan, tetapi untuk guru yang sudah memperoleh pengalaman dengan pelatihan yang ditandai dengan sertifikasi pendidik persentasenya sedikit lebih baik dibanding dengan yang belum mendapat sertifikasi pendidik.

\section{PENUTUP}

Berdasarkan hasil pengujian didapatkan bahwa respon pemahaman sains mahasiwa PGSD dan Guru Sekolah Dasar di Sumedang mempunyai nilai rata-rata persentase 68,7 $\%$ termasuk kategori baik. Hasil analisis one way anova, terdapat perbedaan yang signifikan pemahaman hakikat sains di era digital antara mahasiswa tingkat 3 dengan mahasisiwa tingkat 5. Kemudan berdasarkan rata-rata nilainya, pemahaman mahasiswa tingkat 5 lebih baik dibandingkan yang lainnya. Mahasiswa tingkat 5 dengan guru tidak berbeda secara signifikan, begitu juga antara pemahaman guru dan mahasiwa tingkat 3 tidak terdapat perbedaan yang signifikan. Pemahaman NOS laki-laki dan perempuan tidak berbeda secara signifikan. Sedangkan guru yang sudah memperoleh sertifikasi pendidik tidak jauh berbeda dengan guru yang belum sertifikasi. Secara keseluruhan pemahaman hakikat sains mahasiswa calon guru dan guru sekolah dasar di era digital mempunyai kategori baik.

\section{DAFTAR PUSTAKA}

Abd-El-Khalick, F., Bell, R. L., \& Lederman, N. G. (1998). The nature of science and instructional practice: Making the unnatural natural. Science education, 82(4), 417-436. http://dx.doi.org/10.1002/(SICI)1098-237X(199807)82:4<417::AIDSCE1>3.0.CO;2-E

Adi, Y. K., \& Widodo, A. (2018). Pemahaman hakikat sains pada guru dan siswa sekolah $\begin{array}{lllll}\text { dasar. } & \text { Edukasi } & \text { Journal, } & 10 & \text { (1), }\end{array}$ https://doi.org/10.31603/edukasi.v10i1.1831

Afandi, A., Junanto, T., \& Afriani, R. (2016). Implementasi Digital-Age Literacy dalam Pendidikan Abad 21 di Indonesia. Paper presented at the Prosiding SNPS (Seminar Nasional Pendidikan Sains).

Annisa, M. (2017). Pemahaman aspek-aspek dalam hakikat sains (nature of science) oleh guru sekolah dasar di wilayah 4P (pedalaman, perbatasan, perkotaan, dan pesisir). Jurnal Ilmiah Sekolah Dasar, 1 (4), 241-246, http://dx.doi.org/10.23887/jisd.v1i4.12709

Irzik, G., \& Nola, R. (2014). New directions for nature of science research. International handbook of research in history, philosophy and science teaching (pp. 9991021): Springer.

Jumanto, J., \& Widodo, A. (2018). Pemahaman hakikat sains oleh siswa dan guru SD di kota Surakarta. Jurnal Komunikasi Pendidikan, 2 (1), 20-31. 
Formatif: Jurnal Ilmiah Pendidikan MIPA

Vol. 9, No. 2, Juni 2019, pp. 161-172

p-ISSN: 2088-351X

e-ISSN: $2502-5457$

DOI: http://dx.doi.org/10.30998/formatif.v9i2.3251

Kereluik, K., Mishra, P., Fahnoe, C., \& Terry, L. (2013). What knowledge is of most worth: Teacher knowledge for 21 st century learning. Journal of Digital Learning in Teacher Education, 29 (4), 127-140. http://dx.doi.org/1080/21532974.2013.10784716

Lederman, N. G., Abd-El-Khalick, F., Bell, R. L., \& Schwartz, R. S. (2002). Views of nature of science questionnaire: Toward valid and meaningful assessment of learners' conceptions of nature of science. Journal of Research in Science Teaching, 39 (6), 497-521. https://doi.org/10.1002/tea.10034

Lemke, C. (2002). enGauge 21st Century Skills: Digital Literacies for a Digital Age.

McComas, W. F. (2015). The nature of science \& the next generation of biology education. The American Biology Teacher, 77 (7), 485-491. http://dx.doi.org/10.1525/abt.2015.77.7.2

McComas, W. F., \& Nouri, N. (2016). The nature of science and the next generation science standards: Analysis and critique. Journal of Science Teacher Education, 27 (5), 555-576. http://dx.doi.org/10.1007/s10972-016-9474-3

Muiz, A., Wilujeng, I., Jumadi, J., \& Senam, S. (2016). Implementasi model susan loucks-horsley terhadap communication and collaboration peserta didik SMP. Unnes Science Education Journal, 5 (1). https://doi.org/10.15294/usej.v5i1.9565

Nielsen, K. H. (2013). Scientific communication and the nature of science. Science Education, 22 (9), 2067-2086. https://doi.org/10.1007/s11191-012-9475-3

Olson, J. K. (2018). The Inclusion of the Nature of Science in Nine Recent International Science Education Standards Documents. Science \& Education, 1-24. https://doi.org/10.1007/s11191-018-9993-8

Ratnawati, E. (2013). Pemahaman Hakikat Sains (NOS) Mahasiswa Tahun Ketiga Program Studi Pendidikan Kimia Universitas Negeri Malang. Skripsi Jurusan Kimia-Fakultas MIPA UM.

Siemens, G. (2014). Connectivism: A learning theory for the digital age.

Tjandrawinata, R. R. (2016). Industri 4.0: revolusi industri abad ini dan pengaruhnya pada bidang kesehatan dan bioteknologi. Jurnal Medicinus, 29 (1).

Trilling, B \& Fadel, C. (2009). 21 st Century skills; learning for life in our times. US: Jossey-Bass A Wiley Imprint. 